films; the priming of wood; the weathering of textiles; viscometry; and mathematical studies. The report concludes with lists of the various personnel and their status, the numerous publications by members of the staff of the Laboratories and the names of the various governmental and other committees on which the establishment has been represented.

\section{GEOGRAPHY IN JAPAN}

$\mathrm{T}$ HE International Geographical Union normally sponsors a World Congress every four years, the last two being held at Rio de Janeiro (1956) and Washington (1952). Although much scientific work is being carried on continually through a series of a dozen Commissions, the Executive tried the experiment of holding a Regional Conference of more limited scope than a main Congress, and with a definite field of work. Following the success of the first such Regional Conference on Africa at Makerere in 1955 , the Executive gave its support to the proposal of the Japanese National Geographical Committee under the chairmanship of Prof. Fumio Tada (University of Tokyo) that it should organize a Regional Conference in Japan. The Conference was held during August 28-September 3, with the support of the Science Council of Japan and of numerous universities and municipalities at Tokyo and Nara. The programme, which also included a symposium on South-East Asia and a range of papers in nine sections, centred on the problems of monsoon Asia in general, and Japan in particular, and afforded to the eighty delegates from overseas an opportunity of seeing and appreciating the work of Japanese geographers.

The Conference was preceded by two long excursions, to Hokkaido and northern Honshu, and followed by three others to central and western Japan. The substantial guide books prepared for these excursions were arranged to form a complete regional geography of Japan which, together with a summary volume, afforded the first geographical description of Japan in English written entirely by Japanese authors. Although summaries of original papers in Japanese have long been added in a Western European language (in recent years usually in English), the main work of Japanese geographers has remained little known to Western workers. A comprehensive exhibition of the maps published officially by the Geographical Survey Institute under the direction of Akira Watanabe (one of the secretaries of the Conference) showed examples not only of the large range of geographical and geological maps, but also of many specialized cartographical experiments which have scarcely been seen outside Japan, including a number still in manuscript. The delicacy of old Japanese art is reflected in the many beautiful examples of modern map production and printing. In a country where pressure of population on limited land resources is so extreme that each acre of eultivated land must support six or seven persons in food, it is natural that special attention should be paid to the accurate portrayal of land forms and land use.

In particular, Japan has accepted the principle that to map accurately the existing use or non-use of land is an essential prelude both to understanding the present position and to planning for the future. By mid-1957 no less than 300 sheets on the seale of
$1: 50,000$ of the land use map had been completed $\rightarrow$ roughly a third of the whole country excluding Hokkaido. This work is financed in the main by the prefectural governments, and the maps, undoubtedly the finest and most detailed produced anywhere in the world, have not been placed on public sale. The classification of land use follows the scheme advocated by the World Land Use Survey and Commission of the International Geographical Union, but with many refinements to meet local conditions. In a country primarily dependent upon rice, there is an important distinction between paddy lands and land for other crops ; the determining factor both in this case and in other forms of land use is often degree of slope. Accordingly, experimental maps have been produced, also on the scale of $1: 50,000$, of slope, land-form and valley-density. The slope map displays seven categories of slopes ranging from more than 40 deg. to less than 3 deg. The valley-density maps shows valleys revealed by air photographs to be suffering from gullying and degradation, and records the number of such valleys per square kilometre. The land-form classification map is an ambitious attempt, combining a classification based primarily on different types of hill lands, uplands and terraces and lowlands with a symbolic representation of surface geology and a scheme of minor physiographical regions. An explanation published (in English) in the Bulletin of the Institute in March 1955 urges that such work must precede soil surveys as understood in other countries and of which Japan has published also one experimental sheet (1953). The dependence of Japan for protein on fish has led to much attention being given to the mapping of details of the sea floor and of marine deposits around the islands. The numerous other fields of original study were well shown in the 130 papers contributed to the nine working sections.

A volume of abstracts was printed in advance, and it is planned to publish a comprehensive report of the Conference. Among the foreign participants were the president of the International Geographical Union, Prof. Hans Ahlmann (Sweden), the two immediate past-presidents, Prof. L. Dudley Stamp (United Kingdom) and Prof. G. B. Cressey (United States), the secretary-treasurer, Prof. Hans H. Boesch (Switzerland), and the past vice-president, Prof. G. Kuriyan (India). I. Dudeex Stamp

\section{MAKING AND BREAKING POLYMER MOLECULES}

$R$ ECENT advances in polymer chemistry of especial current interest wore reviewed under the title "Making and Breaking Polymer Molecules" at the second session of Section B (Chemistry) of the British Association held in Dublin on September 9. At the invitation of Dr. J. W. Cook, president of the Section, Prof. C. Kemball took the chair and introduced the following contributions: "The Mechanico-chemistry of Polymers", by Dr. L. Bateman (British Rubber Producers' Research Association); "Stereospecific Polymerizations", by Prof. H. F. Mark (Polytechnic Institute of Brooklyn); "Synthetic Polypeptides as Models for Natural Proteins", by Dr. C. H. Bamford (Courtaulds, Ltd., Maidenhead); and "Plastics for" Use ; Designing Molecules for Particular Purposes", by Dr. C. W. Bunn (Imperial Chemical Industries, Plastics Division). 